DOI: https://doi.org/10.31392/NZ-npu-143.2019.09

УДК 355.357:355.237(043) Г79

ORCID 0000-0003-4090-8980

Гребенюк Л. В.

\title{
СТАН СФОРМОВАНОСТІ \\ IНШОМОВНОÏ КОМУНІКАТИВНОÏ КОМПЕТЕНТНОСТІ У МАЙБУТНІХ ОФІЦЕРІВ ЗСУ В ПРОЦЕСІ ПІДГОТОВКИ У ВИЩОМУ ВІЙСЬКОВОМУ ЗАКЛАДІ ОСВІТИ
}

У статті висвітлено аналіз та стан сформованості іншомовної компетентності військовослужбовиів Збройних Сил України (далі - ЗСУ) крізь призму готовності їх до подальшої професійної взаємодії у міжнародних операціях на основі анкетування особового складу вищих військових навчальних закладів (далі - ВВНЗ). Оскільки вимоги до сучасного офічера ЗСУ та прискорений перехід на військові стандарти НАТО ставить процес іншомовної комунікативної підготовки на якісно інший рівень. Взаємосумісність людського ресурсу часто лишається поза увагою і передбачає успішне вирішення поточних проблем, як само собою зрозуміле явище. Проте, вимоги до сучасного офіиера ЗСУ та пришвидшений перехід на військові стандарти НАТО ставить проиес іншомовної комунікативної підготовки на якісно інший рівень, значно вищий ніж минулі роки. У изьму випадку компетентнісний підхід набуває широкого значення, і його можна розглядати в межах різних сфер діяльності офіиера, основу якого складає реальна готовність фахівия до виконання функиіональних службових обов'язків за отриманою спеціальністю (спеціалізацією).

Визначено, що респонденти одноголосно вказали на надзвичайну важливість та актуальність формування іншомовної компетентності, яка допомагає ӥм якнайшвидме адаптуватися до складних умов проходження служби та налагодженню комунікаиії з іноземними колегами. Результати опитування довели, що саме інтерактивні методи у навчанні іноземної мови, вносять суттєві корективи в ефективність засвоєння іншомовного матеріалу, покращення вивчення лексики та іншомовної термінології, стимулюють формування навичок говоріння та аудіювання та вивчення культурних особливостей вербальної $і$ невербальної комунікації.

Ключові слова: майбутні офіцери, готовність, розвиток, іншомовна компетентність, взаємодія, іррове навчання.

Коли йдеться про взаємосумісність у міжнародних операціях з підтримання миру і безпеки це, переважно, стосується сумісності апаратного та програмного забезпечення, військової техніки та озброєння. Такий зв'язок, сам по собі, має обов'язково поєднуватися 3 взаємосумісністю між людьми, процесами та організаційними складовими миротворчої діяльності. Взаємосумісність людського ресурсу завжди лишається поза увагою і передбачає успішне вирішення поточних проблем, як само собою зрозуміле явище. Проте, вимоги до сучасного офріцера ЗСУ та пришвидшений перехід на військові стандарти НАТО ставить процес іншомовної комунікативної підготовки на якісно інший рівень, значно вищий ніж минулі роки [2; 6]. У цьому випадку компетентнісний підхід набуває широкого значення, і його можна розглядати в межах різних сфрер діяльності офріцера, основу якого складає реальна готовність фрахівця до виконання функціональних 
службових обов'язків за отриманою спеціальністю (спеціалізацією) [3]. Саме тому нами було здійснено анкетування особового складу, серед курсантів, офіцерів та військовослужбовців-контрактників, щоб отримати вичерпну інформацію щодо сучасного стану сфрормованості іншомовної комунікативної компетентності, підходів до іншомовної підготовки для покращення та внесення змін у процес пізнавальної діяльності на навчального процесу.

Аналіз останніх досліджень і публікацій показує, що компетентність як наукову категорію розкривали В.В.Балабін, О.В.Діденко, В.І. Свистунов, В.В.Ягупов. Поняття іншомовної компетентності описували та надавали обґрунтування В.В. Балабін, І. С. Бахов, Г. К. Іванчук, О. В. Нечипорук, Н. В. Чіжова. Питаннями фрормування іншомовної компетентності займалися такі науковці як І.В.Атаманова, Н. А. Копилова, М. М. Моцар, Л. В. Петько, І. В. Ставицька, В. В. Черниш, Н. П.Шалигіна, Н.В.Яцишина. Іншомовну компетентність як інтегративне утворення особистості трактує О. В. Нечипорук.

Mema cmammi - проаналізувати та визначити стан сформованості іншомовної комунікативної компетентності у ВВНЗ крізь призму готовності військовослужбовців ЗСУ для подальшої професійної взаємодії у міжнародних операціях із підтримання миру і безпеки.

Знання іноземної мови, володіння мовною культурою не розкіш, а вимоги часу - в сучасному, швидко змінюваному світі високих технологій, міжкультурних контактів та інтеграційних процесів ця істина вже не потребує доказів. Численні соціологічні опитування свідчать про визнання людиною XXI століття існування простої закономірності: чим вільніше ти володієш іноземною мовою, тим ширше і цікавіше твоє коло спілкування, швидкий кар'єрний ріст та результативна пізнавальна діяльність.

Н. П. Шалигіна провела системний аналіз наукових джерел та визначила комунікативну компетентність офріцерів багатонаціональних штабів, як складне інтегративне професійно важливе утворення, яке проявляється у їхній підготовленості, здатності та готовності налагоджувати, встановлювати, підтримувати й розвивати успішну міжособистісну та особистісно-групову професійну взаємодію в різноманітних ситуаціях службово-ділового спілкування в умовах іншомовного військово-профресійного середовища $[8 ; 9 ; 10 ; 14 ; 15]$.

Навчальна діяльність принципово нічим не відрізняється від інших видів діяльності. Проте необхідно володіти певним набором прийомів, щоб їі здійснювати. Для нашого дослідження аналізу стану і сформованості іншомовної комунікативної компетентності в процесі практичної підготовки у ВВНЗ як основи готовності майбутніх офріцерів ЗСУ до професійної взаємодії у міжнародних військових операціях з підтримання миру і безпеки ми можемо використати три рівні, запропоновані Ю. І. Пассовим та Н. Ю. Кузовлевою, володіння інформацією для досягнення достатнього рівня, тобто рівня “автоматизації” спілкування [5].

Перший рівень - слухач чітко знає і ясно уявляє собі всі “заплановані" кроки діяльності, може назвати і необхідну послідовність кроків, і можливість застосування тих чи інших прийомів у залежності від умов навчання, але сам жодного разу не здійснював цієї діяльності.

Другий рівень - ("знає - вміє") починається з того, що слухач, керуючись пам'яткою, безліч разів здійснює прийом (серію прийомів) навчальної діяльності, 
звіряючи свої кроки з пам'яткою, що лежить перед ним або що зберігається в його пам'яті. У другому випадку справа буде просуватися успішніше. Як результат слухач уміє виконувати відповідний прийом, але робить це, усвідомлюючи, як він це робить, відволікаючи свою довільну увагу на технічну сторону справи, отже, витрачаючи на прийом більше часу, ніж треба.

Третій рівень - рівень володіння прийомом. Слухач, спираючись на чітко усвідомлені уявлення стосовно кожного наступного етапу, не усвідомлює їх у процесі діяльності, “автоматизація" виконує прийом або серію прийомів навчальної діяльності, що лежать в основі вправи (завдання). Це означає, що технічна сторона вправи не відволікає уваги слухача, він не думає про неї. Прийом здійснюється на рівні навички: слухач володіє прийомом.

Наголосимо, що з позиції діяльнісного підходу, мислення і мова являють собою не суму, а єдність. Специфіка такої єдності полягає в тому, що обидва ці процеси (мислення і мова) не можуть бути зведені один до одного (ототожнені), точно так само, як вони не можуть бути відірвані один від одного. Тим часом у методиці навчання іноземних мов основна увага приділяється мові. Щоб переконатися в цьому, досить відкрити методичні посібники, монографії, дисертації, де ми стикаємося з такими поняттями як "мовна навичка", "мовне вміння", "мовна вправа", інакше кажучи, - технології навчання іноземних мов розробляються, як правило, з урахуванням закономірностей мови, фрормування мовних навичок і мовленнєвих умінь; мислення при цьому або ігнорується, або мається на увазі (в надії, що воно саме приплюсується до мовної навички або вміння). На нашу думку, тут криється одна з методологічних помилок, яка гальмує розвиток методики навчання іноземних мов за лінією комунікативності.

3 метою з'ясування ставлення військовослужбовців ЗСУ до іноземної мови (англійської) та визначення значення застосування отриманих у ВВНЗ мовленнєвих знань під час виконання завдань у міжнародних операціях із підтримання миру і безпеки було здійснено анонімне анкетування військовослужбовців. Додатково опитування також дало можливість виявити проблемні питання у вивченні іноземної мови з метою подальшого вдосконалення навчального спецкурсу з іншомовної підготовки.

У констатувальному експерименті взяли участь 3 категорії військовослужбовців: 1) офріцери (125 осіб); 2) курсанти ВВН3 (295 осіб); 3) військовослужбовці військової служби за контрактом (контрактники) 104 особи.

Усього кількість респондентів становила 524 респонденти, які мали загальне поняття про вищезазначений курс підготовки з іноземної мови та відповідні знання, вміння та навички. Анкетування проводилось у ВВНЗ серед постійного та змінного офіцерського складу, офіцерів, які прибули для проходження курсів підвищення кваліфікації, курсантів ВВНЗ та контрактників, що проходять спеціальне навчання для отримання первинного офріцерського звання. Відсоток опитуваних офріцерів з вислугою до 10 років становив 65,6\% (82 особи), 3 вислугою більше 10 років 34,4\% (18 осіб). В той самий час, серед контрактників значно більша частина військовослужбовців мала понад 10 років вислуги, а саме - 85 осіб (81,7\%) та менше 10 років - 19 осіб (18,3\%) відповідно. Одним з питань анкетування була участь опитуваних в Антитерористичній операцій та Операції 
об'єднаних сил. Згідно з отриманими даними відсоток таких військовослужбовців становить 75\% серед офріцерів та контрактників та 6\% - серед курсантів. Із 524 респондентів участь у міжнародних операціях брали 63 військовослужбовці (12\%).

Отже, 119 респ. (95,2\%) із офріцерського складу визнали високу необхідність володіння іноземною мовою військовослужбовцями ЗСУ. Своєю чергою, такий відсоток серед курсантів становив 85,4\% (252 респ.). Аналіз показує, що існує нагальна потреба у володінні іноземною мовою серед військовослужбовців. Показник потреби знання іноземної мови серед опитаних офріцерів більш високий, ніж у контрактників та курсантів. Ми можемо пояснити це тим, що такі офріцери та контрактники безпосередньо брали участь у міжнародних операціях з підтримання миру і безпеки та практикували спілкування з іноземними колегами, де загально мовою міжособистісного (приватного) та службового спілкування є англійська мова.

Серед варіантів необхідного рівня володіння іноземною мовою для здійснення професійної діяльності офріцера були запропоновані такі рівні:

- "на рівні професіонала (носія) мови";

- "вільне володіння та спілкування на професійні теми";

- "спілкування на загальному (побутовому) рівні";

- "необхідний мінімум знань та словникового запасу, для того, щоб здійснювати елементарне спілкування (комунікацію)";

- "висловлювання думки за допомогою електронного перекладача".

Майже одноголосно усі три групи респондентів визначили, що офріцер повинен вільно володіти іноземною мовою та здійснювати комунікацію за профресійною тематикою.

Оцінки рівня реального володіння іноземною мовою значно різнилися від бажань опитуваних. Лише 21 респ. (20,2\%) із числа контрактників оцінили свою здатність вільно говорити іноземною мовою на професійну тематику, 38 респ. $(36,5 \%)$ - здатні спілкуватися лише на побутовому рівні, тоді як необхідний мінімум знань мають 43 респ. (41,3\%), інші можуть висловлювати думки за допомогою електронного перекладача. Серед курсантів цей показник склав 40\% (118 респ.), які здатні вести професійну розмову англійською мовою, проте відсоток тих, хто спілкується на початковому рівні залишається досить високим, і на побутовому рівні він становить 88 осіб $(29,8 \%)$, а на найнижчому у 89 осіб $(30,2 \%)$, особливо це стосується курсантів немовних спеціальностей. Відповідаючи на питання про власний рівень знань з іноземної мови, показники офріцерів, які вільно володіють мовою - 63 респ. (50,4\%), коли 48 осіб $(38,4 \%)$ здатні вести розмови на побутову тематику і 14 військовослужбовців $(11,2 \%)$ оцінили себе як початківців у володінні мови.

Як і очікувалося, найскладнішими видами мовленнєвої діяльності під час вивчення іноземної мови стали “говоріння" та “аудіювання", 455 осіб (86,8\%). Вважаємо ці види мовленнєвої діяльності найбільше відповідають потребам військовослужбовців, які будуть здійснювати міжмовну та міжкультурну комунікацію під час виконання службових обов'язків у міжнародних операціях 3 підтримання миру і безпеки.

430 (82\%) військовослужбовців погодилися, що у вік розвитку інформаційних технологій та переходу ЗСУ на військові стандарти НАТО впровадження інтерактивних методів навчання, а саме рольових та ділових ігор, процес 
підготовки сучасного офріра потрібно значно інтенсифікувати, щоб вивести на належний рівень знання іноземної мови для прискорення досягнення взаємосумісності з іноземними партнерами. Серед побажань щодо внесення коректив у процес вивчення мови були такі методи: використання інтернеттехнологій та практичних ситуативних завдань (кейс метод [7; 13]), організація круглих столів, дебатів, обговорень, презентацій англійською мовою, читання сучасних автентичних діалогів та текстів, відпрацювання розмовних кліше та термінів, усунення стандартних підходів у вивченні мови, враховуючи сучасні виклики іншомовного суспільства.

Після анкетування відбувся круглий стіл із військовослужбовцями, які мають досвід участі у міжнародних операціях з підтримання миру і безпеки. Одноголосно респонденти вказали на надзвичайну важливість та актуальність фрормування іншомовної компетентності, яка допомогла їм якнайшвидше адаптуватися до складних умов проходження служби та налагодити комунікацію з іноземними колегами.

Навички спілкування $є$ одними з визначальних ознак компетентного офріцеракомунікатора, адже основним завданням усіх командирів, штабних офіцерів та начальників $є$ зробити так, щоб люди (офіцери) правильно виконували поставлені задачі та команди. Це означає, що такі офріцери повинні вміти чітко та ясно доводити інформацію до підлеглих іноземною мовою. Також потрібно враховувати уміння військовослужбовця працювати у команді. Природня конкуренція серед військових та конкуренція серед країн може стати серйозною проблемою та порушити злагодженість підрозділу [7; 15]. Через що, фрормування іншомовної компетентності, де одним з ключових фракторів $€$ знання культури мовця, може сприяти переосмисленню поведінки цілого підрозділу та формуванню розуміння, що всі учасники міжнародних операцій є однією командою [4].

Профресор І. С. Бахов наголошує, що особливості невербальної комунікації також відображають нашу культуру і можуть призводити до непорозумінь між групами людей [1]. Доречність рукостискання, поклонів або цілування людей під час привітання варіюються в різних культурах. Культура також визначає те, як ми ходимо, сидимо, стоїмо, спираємося, жестикулюємо й танцюємо. Підіймання брови та жестикуляція руками має різний зміст у різних групах; такі дії можуть бути прийнятними й очікуваними в одній групі й дуже образливими чи грубими в іншій. Ми маємо нагадувати собі, що не можна інтерпретувати дії та вирази обличчя людей з іншої культурної групи як неправильні або недоречні лише тому, що вони не такі, як наші. Така поведінка є культурно обумовленою [14].

До того ж, респонденти зауважують, що важливою складовою іншомовної компетентності $€$ невербальна комунікація:

- дотики - у кожній країні вони можуть мати своє значення, наприклад батько потискає руку сину, але обіймає дочку; тримання за руки в одній країні $€$ виявом товариськості, у іншій - неприпустимим явищем;

- особистий простір - іноді вам може бути лячно від того, наскільки близько стоять представники деяких країн, проте, коли хтось стоїть занадто далеко, також нетипово для нашої культури;

- рухи та жести - неодноразово можуть виникати непорозуміння пов'язані з мовою тіла, виразом обличчя, поглядом. наприклад, у нашій країні сержант 
чекатиме, що ви будете дивитися йому у вічі (як вияв поваги), проте у культурі солдата вияв поваги - це очі опущені вниз;

- час - різниця у тому як представники різних країн сприймають час. дехто каже, що час - це гроші, його не потрібно марно витрачати, інші вважають, що потрібно бути більш гнучкими та менш прискіпуватися до часових рамок.

Також серед курсантів було проведено опитування щодо визначення значення “іншомовної компетентності” для виконання обов'язків у міжнародних операціях з підтримання миру і безпеки. Більшість курсантів знають що таке міжнародні операції та планують брати участь у них. Важливість іншомовної підготовки підтвердили 90\% респондентів. Проте, 95\% респ. визнали, що іншомовна підготовка у ВВН3 тільки частково відповідає вимогам Збройних сил.

Висновки. Отже, результати опитування військовослужбовців показали, що для ефективної іншомовної взаємодії та уникнення конфліктних ситуацій варто враховувати усі зазначені вище особливості. Саме інтерактивні методи навчання можуть внести суттєві корективи у ефективність засвоєння матеріалу іноземною мовою, прискорення вивчення слів та термінології, формування навичок говоріння та аудіювання, вивчення культурних особливостей вербальної та невербальної комунікації.

\section{Використана література:}

1. Бахов I. С. Міжкультурний компонент як основа формування міжкультурної компетенції майбугніх перекладачів. Наукові записки. Серія “Філологічна”. 2010. № 16. С. 18-25.

2. Захарчишина Ю. М. Педагогічні умови підготовки офіцерів Збройних Сил України до соціокультурної діяльності в миротворчих місіях : автореф. дис. ... канд. пед. наук : 13.00.04 / Житомирський держ. ун-т імені Івана Франка. Житомир, 2011. 20 с.

3. Нещадим М. I. Військова освіта в Україні: історія, теорія, методологія, практика : [монографія]. Київ : ВПЦ “Київський університет”, 2003. 852 с.

4. Павлов Я. Понятійно-категоріальний апарат розвитку готовності офіцерів до миротворчої діяльності. Вісник Національної академії Державної прикордонної служби Украӥни. Педагогічні науки. 2016. № 2.

5. Пассов Е. И., Кузнецова Н.Е. Основы коммуникативной теории и технологии иноязычного образования: методическое пособие для преподавателей русского языка как иностранного. Москва : Русский язык. Курсы, 2010. 586 с.

6. Петько Л. В. Виклики XXI століття для освітнього простору України. Наукові праці [Чорноморського державного університету імені Петра Могили комплексу “Києво-Могилянська академія"]. Серія : Педагогіка : наук. журн. / Чорном. держ. ун-т імені Петра Могили; ред. кол. : О. П. Мещанінов (голова) [та ін.]. - Миколаїв : Вид-во ЧНУ імені Петра Могили, 2017. Т. 303. Вип. 291. С. 10-14.

7. Петько Л. В. Виховний потенціал методу ситуаційного аналізу (“Case study” method) у формуванні професійно орієнтованого іншомовного навчального середовища в умовах університету. Науковий часопис НПУ імені М. Д. Драгоманова. Серія 17. Теорія і практика навчання та виховання : зб. наук. пр. ; за ред. академіка В. І. Бондаря. Київ : Вид-во НПУ імені М. П. Драгоманова, 2015. Вип. 27. С. 133-140.

8. Петько Л. В. Інноваційні технології навчання у формуванні професійно орієнтованого іншомовного навчального середовища // Сучасні технології розвитку професійної майстерності майбутніх учителів: матеріали Всеукраїнської Інтернет-конференції, 28 жовтня 2015 р. // FOLIA COMENIANA: вісник Польсько-української науково-дослідної лабораторії дидактики імені Я. А. Коменського. Умань : ФОП Жовтий, 2015. С. 165-170.

9. Турчинова Г. В. Психолінгвістичні передумови оволодіння іноземною мовою для спеціальних цілей. Наукові записки: [збірник наукових статей] / М-во освіти і науки, молоді та спорту України, Нац. пед. ун-т імені М. П. Драгоманова ; укл. Л. Л. Макаренко. - Київ : Вид-во НПУ імені М. П. Драгоманова, 2011. Вип. LXXXXVIII (98). С. 201-207. 
10. Шалигіна Н. П. Розвиток комунікативної компетентності офіцерів багатонаціональних штабів у процесі військово-професійної підготовки до участі в міжнародних миротворчих операціях : автореф. дис. ... канд. пед. наук: 13.00.04. / Національний ун-т оборони України імені Івана Черняховського. Київ, 2019. 22 с.

11. U.S. Military Culture and Training Environment. Defense Language Institute, 2019. 191 p.

12. Bakhov I., Ryzhykov V., Kolisnyk O. Leadership Abilities of a Military Manager, Professionalism of a Commander as the Guarantee of the Practice of Effective Activity of a Military Organization. International Journal of Engineering \& Technology; Vol 7, No 4.38 (2018): Special Issue 38. P. 45-49.

13. Pet'ko Lyudmila. The "Case Study" Method as Means of Formation of a Professionally Oriented Foreign Language Teaching Environment in University Conditions [Метод ситуаційного аналізу ("case study" method) як засіб формування професійно орієнтованого іншомовного навчального середовища в умовах університету]. Intellectual Archive. 2015. Volume 4. No. 4 (July). Series "Education \& Pedagogy". Toronto : Shiny Word Corp. Pp. 48-65. URI http://enpuir.npu.edu.ua/handle/123456789/7974

14. Ryzhykov V. Method of organizing lessons in the armies in the way of modern world military educational practice. Problems of the development of modern science: theory and practice: Collection of scientific articles. EDEX, Madrid, España, 2018. P. 218-228.

15. Ryzhykov V. A Technology of Development of the Lawyer's Psychogram and its Meaningful and Practical Component. Journal of Advanced Research in Law and Economics. Vol. 2016. VII. Issue 1(15) Spring, P. 100-108. DOI: http://dx.doi.org/10.14505/jarleSci Verse Scopus

\section{References:}

[1] Bakhov I. S. (2010) Mizhkulturnyi component yak osnova formuvannia mizhkulturnoi kompetentsii maibutnih perekladachiv. Naukovi zapysky. Seriya Filologichna, No. 16. Pp 18-26.

[2] Zakharchyshyna Yu. M. (2011) Pedagogichni umovy pidgotovky ofitseriv Zbroinyh Syl Ukrainy do sotsiokulturnoyi diyalnosti v myrotvorchykx misiyakh: Extended abstract of candidate`s thesis. Zhytomyr. 20 p.

[3] Neshchadym M. I. (2003) Viiskova nauka v Ukraini: istoriya, teoriya, metodologiya, praktyka: monograph. Kyiv: VPTS Kyivskyi universyte. 852 p.

[4] Pavlov Ya. (2016) Poniatiino-kategorialnyi apparat rozvytku hotovnosti ofitsera myrotvorchoi diyalnosti. Visnyk Natsionalnoii Akademii Derzhavnoi prykordonnoi sluzhby Ukrainy. Seriya: Pedagogika. No. 2.

[5] Passov E. I. 2010. Osnovy komunikativnoi teorii I technologii inoyazychnogo obrazovaniya: metodicheskoe posobie dlya prepodavatelei russkogo yazyka kak inostrannogo. Moskva: Russkii yazyk. Kursy. $586 \mathrm{p}$.

[6] Petko L. V. (2017) Vyklyky XXI stolittia dlia osvitnoho prostoru Ukrainy. Naukovi pratsi [Chornomorskoho derzhavnoho universytetu imeni Petra Mohyly kompleksu "Kyievo-Mohylianska akademiia"]. Seriia : Pedahohika : nauk. zhurn. / Chornom. derzh. un-t imeni Petra Mohyly; red. kol. : O. P. Meshchaninov (holova) [ta in.]. Mykolaiv: Vyd-vo ChNU imeni Petra Mohyly. Vol. 303. Vyp. 291. P. 10-14.

[7] Petko L. V. (2015) Vykhovnyi potentsial metodu sytuatsiinoho analizu ("Case study" method) u formuvanni profesiino oriientovanoho inshomovnoho navchalnoho seredovyshcha $\mathrm{v}$ umovakh universytetu. Naukovyi chasopys NPU imeni M. D. Drahomanova. Seriia 17. Teoriia i praktyka navchannia ta vykhovannia : zb. nauk. pr. ; za red. akademika V. I. Bondaria. Kyiv : Vyd-vo NPU imeni M.P.Drahomanova. Vyp. 27. P. 133-140. URI http://enpuir.npu.edu.ua/handle/123456789/7974

[8] Pet'ko L. V. (2015) Innovacijni tehnologii navchannja u formuvanni profesijno orintovanogo inshomovnogo navchal'nogo seredovishha //Suchasni tehnologiï rozvitku profesijnoï majsternosti majbutnih uchiteliv: materialy Vseukrains'koï Internet-konferencii, 28 zhovtnja 2015 r. //FOLIA COMENIANA: visnyk Pol's'ko-ukrains'koi naukovo-doslidnoi laboratoriï didaktiki imeni Ja. A. Komens'kogo. Uman: FOP Zhovtij. P. 165-170.

[9] Turchynova H. V. (2011) Psykholinhvistychni peredumovy ovolodinnia inozemnoiu movoiu dlia spetsialnykh tsilei. Naukovi zapysky : [zbirnyk naukovykh statei] / M-vo osvity i nauky, molodi ta sportu Ukrainy, Nats. ped. un-t imeni M. P. Drahomanova ; ukl. L. L. Makarenko. Kyiv: Vyd-vo NPU imeni M. P. Drahomanova. Vyp. LXXXXVIII (98). P. 201-207.

[10] Shalygina N. P. (2019) Rozvytok komunikatyvnoi kompetentnosti ofitseriv bahatonatsionalnykh shtabiv $\mathrm{u}$ protsesi viiskovo-profesiinoi pidgotovky do uchasti u mizhnarodnyh myrotvorchyh operatsiyah: extended abstract of qualifying research paper. $20 \mathrm{p}$.

[11] U.S. (2019) Military Culture and Training Environment. Defense Language Institute. 191 p. 
[12] Bakhov I., Ryzhykov V., Kolisnyk O. 2018. Leadership Abilities of a Military Manager, Professionalism of a Commander as the Guarantee of the Practice of Effective Activity of a Military Organization. International Journal of Engineering \& Technology. Vol 7, No 4.38: Special Issue 38. P. 45-49

[13] Pet'ko Lyudmila. The "Case Study" Method as Means of Formation of a Professionally Oriented Foreign Language Teaching Environment in University Conditions. Intellectual Archive. 2015. Volume 4. No. 4 (July). Series "Education \& Pedagogy". Toronto : Shiny Word Corp. Pp. 48-65.

[14] Ryzhykov V. (2018) Method of organizing lessons in the armies in the way of modern world military educational practice. Problems of the development of modern science: theory and practice: Collection of scientific articles. EDEX, Madrid, España, P. 218-228.

[15] Ryzhykov V. (2016) A Technology of Development of the Lawyer's Psychogram and its Meaningful and Practical Component. Journal of Advanced Research in Law and Economics. Vol. VII. Issue 1(15) Spring, P. 100-108. DOI: http://dx.doi.org/10.14505/jarleSci Verse Scopus

ГРЕБЕНЮКЛ. В. Состояние сформированности иноязычной коммуникативной компетентности у будущих офицеров всу в процессе подготовки в высшем военном учебном заведении.

В статье освещены анализ и состояние сформированности иноязычной компетентности военнослужаших Вооруженных Сил Украины (ВСУ) через призму готовности их к дальнейшему профессиональному взаимодействию в международных операциях на основе анкетирования личного состава высших военных учебных заведений. Поскольку требования к современному офииеру ВСУ и ускоренный переход на военные стандарты НАТО ставит проиесс иноязычной коммуникативной подготовки на качественно иной уровень. Совместимость человеческого ресурса часто остается без внимания, но в то же время, предполагает успешное решение текущих проблем. Однако, требования к современному офицеру ЗСУ и ускоренный переход на военные стандарты НАТО ставит процесс иноязычной коммуникативной подготовки на качественно другой уровень, значительно высший чем прошлье года. В этом случае компетентностный подход имеет большое значение, и его можно рассматривать в пределах разных сфер деятельности офииера, основу которого составляет реальная готовность специалиста к выполнению функииональных служебных обязанностей по полученной специиальности (специализащии).

В исследовании респонденты единогласно указали на чрезвычайную важсность $и$ актуальность формирования иноязычной компетентности, которая помогла бы им быстрее адаптироваться к сложным условиям прохождения службб и наладить коммуникацию с иностранными коллегами. Результаты опроса показали, что именно интерактивные методы обучения могут внести существенные коррективы в эффективность усвоения материала на иностранном языке, ускорении изучения слов и терминологии, в формировании навыков говорения и аудирования, в изучении культурных особенностей вербальной и невербальной коммуникачии.

Ключевые слова: будущие офичеры, готовность, развитие, иноязычная компетентность, ролевые игры, взаимодействие.

HREBENIUK $L$. $V$. The state of foreign language communicative competence formation in the future officers of afu in the training at higher military educational institution.

The article introduces the state of formation of foreign language competence of servicemen through the prism of the readiness of servicemen of the Armed Forces of Ukraine (the AFU) for further professional interaction in international operations on the basis of questionnaires of personnel from higher military educational institutions (the HMEI). The requirements for a modern officer from the $A F U$ and the accelerated transition to NATO military standards put the process of foreign language communication training at a qualitatively different level. However, the requirements for a modern AFS officer and the rapid transition to NATO military standards puts the process of foreign language communication training at a different level, far higher than in recent years. In this case, the competence approach is of broad importance and can be considered within the different spheres of the officer's activity, which is based on the real readiness of the specialist to perform the functional duties of the specialty (specialization) obtained. 
Unanimously, the respondents pointed to the extraordinary importance and relevance of the formation of foreign language competence, which helped them to adapt as quickly as possible to the difficult conditions of service abroad and to establish communication with foreign colleagues. Communication skills are among the key features of a competent communicant officer, since the main task of all commanders, staff officers and bosses is to make sure that people (officers) correctly perform their tasks and commands. importance of foreign language training was confirmed by $90 \%$ of respondents. The results of the survey showed that it is the interactive teaching methods that can make significant adjustments to the effectiveness of mastering learning material in foreign language, speeding up learning of words and terminology, developing skills of speaking and listening, and studying the cultural features of verbal and non-verbal communication.

Keywords: future officers, readiness, development, foreign language competence, interaction, role-playing teaching.

DOI: https://doi.org/10.31392/NZ-npu-143.2019.10

УДК 378.011.3-051:37.016:621.3+621.38]:377

ORCID 0000-0003-0968-1060

Дідик А. 0.

\section{РЕАЛІЗАЦІЯ МІЖДИСЦИПЛІНАРНИХ ЗВ'ЯЗКІВ У ПРОЦЕСІ НАВЧАННЯ ЕЛЕКТРОТЕХНІКИ ТА ЕЛЕКТРОНІКИ}

Проблема реалізації міждисииплінарних зв'язків у процесі вивчення електротехніки $i$ електроніки не втратила свою актуальність і нині. Це одне з найбільш складних методичних завдань викладача, де він повинен сконщентрувати знання з інших дисциплін, поєднавщи їх у иілісну систему.

У статті теоретично обтрунтовано реалізацію міждисииплінарних зв'язків при викладанні електротехніки та електроніки у ВНЗ. Визначено місие $і$ роль курсу загальної фізики, вищої математики, хімії та технічної механіки у процесі вивчення електротехніки та електроніки. Розглянуто навчальний курс “Електротехніка та електроніка”, щзо відіграє важливу роль у впровадженні міждисииплінарних зв'язків, які спрямовані на розв'язання нестандартних рімень на сучасному етапі розвитку суспільства. Електротехніка та електроніка, синтезуючи навколо себе інші дисиипліни, створюють величезний міждисциплінарний потенціал, внаслідок чого діяльність викладача стає більш результативною, успішною, професійною. Конкретизовано навчальні теми ичих курсів, на базі яких основані вивчення електротехніки та електроніки. Продемонстровано шляхи корегування навчальної програми із врахуванням змісту иих курсів, щзо усуває дублювання та повтори.

Установлення міждисииплінарних зв'язків між викладанням курсу електротехніки, електроніки, фізики, хімії, технічної механіки, вищої математики сприяє більш поглибленому засвоєнню знань, наукових понять $і$ законів, вдосконаленню навчально-виховного процесу та оптимальної його організації, формуванню наукового світогляду, єдності матеріального світу, взаємозв'язку явищ у природі й суспільстві. Реалізація міждисииплінарних зв'язків усуває дублювання у вивченні матеріалу, заощаджує час і створює сприятливі умови для формування фахових компетентностей.

Ключові слова: міждисииплінарні зв'язки, електротехніка, електроніка, фізика, хімія, математика, матеріалознавство. 